\title{
スギ花粉症に括ける初期治療の客観的評価
}

\author{
加藤 昌志 ${ }^{112)} \cdot$ 服部 琭 ${ }^{3)} \cdot$ 喜多村真弓 ${ }^{3)}$ \\ 別府 玲子 $33 \cdot$ 柳田 則之 ${ }^{1)}$
}

\section{Objective Evaluation of Prophylactic Treatment for Pollinosis}

\author{
Masashi Kato and Noriyuki Yanagita \\ (Nagoya University) \\ Mayumi Kitamura, Reiko Beppu and Taku Hattori \\ (Nagoya University Branch Hospital)
}

In this objective evaluation of the efficacy of prophylactic treatment for Japanese cedar pollinosis during natural allergen exposure, topical ketotifen $(0.3 \sim 0.4 \mathrm{mg} / \mathrm{day})$ was administered during the spring of 1992. Ten patients received prophylactic treatment, and others were treated after the onset of symptoms. Subjective symptom scores, blood eosinophil counts and serum MBP values were examined and compared.

The total subjective symptom scores, blood eosinophil counts and serum MBP values in the prophylactic treatment group were significantly lower than in the group treated after the onset of symptoms. Thus, the effect of prophylactic treatment can be evaluated objectively.

Key words: ketotifen, MBP, pollinosis, prophylactic treatment, natural allergen exposure

はじめに

ケトチフェンはケミカルメディェーター遊離 抑制作用，抗ヒスタミン作用1) 3) を持つ抗アレ ルギー剂であり，予防的に経口または局所投与 することにより花粉症の自覚症状を軽減できる ことが認められている(4) 6). しかし, 自然飛散 の初期治療の効果が客観的データにて考察され た研究は少ない。

Major basic protein (MBP) は Gleich ら ${ }^{778)} に$ より好酸球より分離された顆粒蛋白である. $\mathrm{MBP}$ は気道上皮細胞に対する上皮の剝離, 線 毛運動の傷害作用9)10), ヒスタミン遊離作用 ${ }^{11)}$
など種々の作用を持ち，アレルギー疾患に深く 関与していることが明らかにされつつある.さ らに, Hisamatsu ら ${ }^{12)}$ はMBPがヒトの上気 道上皮に対して障害性を持つことを, Andrew ら13) は花粉症患者に扣いて粘膜下組織の抗 MBP 抗体が飛散前に比較して飛散期に有意に 上昇していることを報告して扣り，MBP と鼻 アレルギーの関係も注目されはじめている。し かし，MBPの鼻アレルギー病態への関与に対 する詳細な検討は未だ少ない。

今回我々は, 自然飛散状態に打けるスギ花粉 症患者の血中好酸球数および血清 MBP 值など

1）名古屋大学医学部耳鼻咽喉科学教室

2) 名古屋大学医学部免疫学教室

3) 名古屋大学分院耳鼻咽喉科 
を測定し，自覚症状との関係を検討した。ささら に, これらをパラメーターとして用いて初期治 療の効果をより客観的に評価することを目的と して研究を施行した.

\section{対象および方法}

1. 花粉飛散 : 愛知県衛生部発表の1992年度 名古屋地区のスギ花粉の飛散状況を示した （図 1 ）。これに基づき1992年 2 月28日より 4 月
8 日までを飛散期とした

2. 研究計画：スギ花粉症患者のボランティ ア(10例)に対して1992年1月16日よりヶトチフ ェン点鼻 $(0.3 \sim 0.4 \mathrm{mg} /$ 日)のみの初期治療を 施行し，これを初期治療群とした。ささらに，飛 散開始約 2 週間後である1992年 3 月 12 日よりヶ トチフェン点鼻の治療を開始したスギ花粉症患 者のボランティア (10例)を非初期治療群とした.

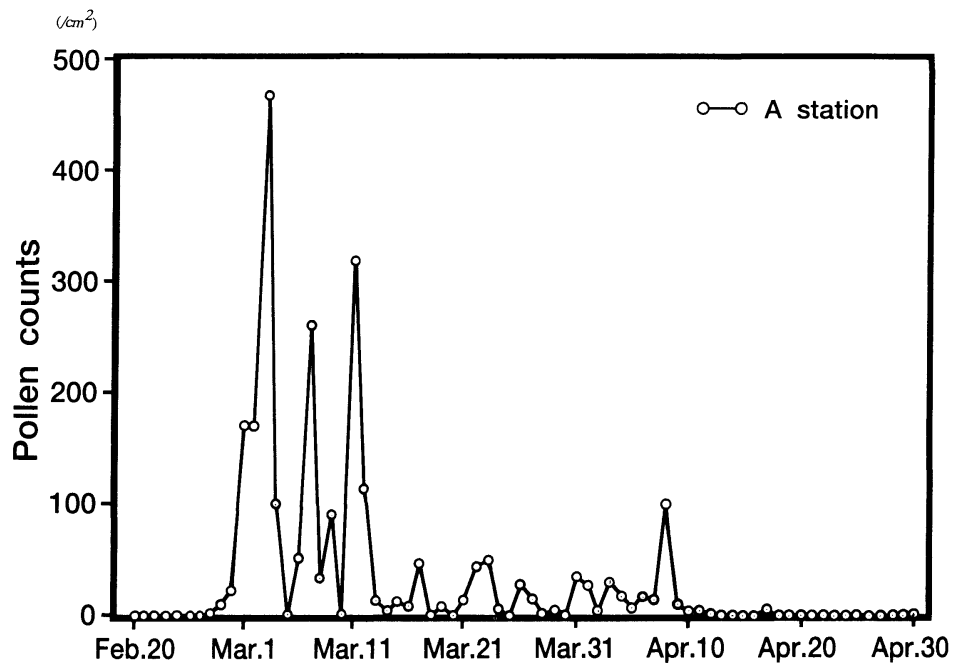

図 1 1992年度名古屋市スギ花粉飛散状況

表 1 鼻閉, 鼻汁, くしゃみ, 嗅覚, 日常生活の支障度に関するアンケート結果

\begin{tabular}{|c|c|c|c|c|}
\hline \multirow{2}{*}{ 種 } & \multicolumn{2}{|r|}{ 程 } & \multicolumn{2}{|l|}{ 度 } \\
\hline & H & $H$ & + & - \\
\hline $\begin{array}{l}\text { くしゃみ發作 } \\
\text { (1日の発作回数) }\end{array}$ & 10 回以上 & $9 \sim 5$ 回 & 4 回以下 & 0 \\
\hline $\begin{array}{l}\text { 鼻 } \text { 汁 } \\
\text { 日の擤鼻回数) }\end{array}$ & 10回以上 & $9 \sim 5$ 回 & 4 回以下 & 0 \\
\hline 鼻 閉 & $\begin{array}{l}\text { 鼻閉が非常に強く呼 } \\
\text { 吸が } 1 \text { 日のうちかな } \\
\text { りの時間あり }\end{array}$ & $\begin{array}{l}\text { 鼻閉が強く, 口呼吸 } \\
\text { が } 1 \text { 日のうち時々あ } \\
\text { り }\end{array}$ & $\begin{array}{l}\text { 口呼吸は全くないが } \\
\text { 鼻閉あり }\end{array}$ & なし \\
\hline 嗅覚異常 & 無臭 & 臭らが弱い & 少し弱い & 正常 \\
\hline 日常生活の支障度 & $\begin{array}{l}\text { 仕事が手につかない } \\
\text { ほど苦しい }\end{array}$ & (H) と (+)の中間 & $\begin{array}{l}\text { 仕事にあまり差し支 } \\
\text { えない }\end{array}$ & 支障なし \\
\hline
\end{tabular}

5 種類の自覚症状について 3 点, \#を 2 点, +を 1 点, 一を 0 点とし，この合計点(15点満点)で総合自 覚症状を評価した。 
飛散期（3 月11日）に自覚症状，血中好酸球数, 血清 MBP 值が測定され，投薬の施行されてい ない非初期治療群に扮いて自覚症状，血中好酸 球数および血清 MBP 值のそれぞれに対する相 関関係を調べるとともに，両群間でこれらのパ ラメーターが比較された. 尚, 1992年の名古屋 地区の花粉飛散量は平年に比べてかなり少なか ったため, 両群とも飛散終了までケトチフェン 点鼻以外の薬剤は使用しなかった。

3. 対象：患者はすべて毎春鼻閉，〈しゃみ, 鼻汁などの鼻アレルギー症状が出現し, RAST がスギのみ+H上陽性で，他に鼻疾患 を有しない者とした。初期治療群は10名(平均 年歯 34 歳), 非初期治療群は10名 (平均年齢33歳) である。両群間に沶いて臨床症状の既往歴およ びRAST スコアーに有意差は認めなかった。

4. 自覚症状の評価: 両群とも 3 月 11 日に鼻 閉, 鼻汁, 〈しゃ及, 嗅覚, 日常生活の支障度 に関するアンケート(表 1)を施行し ${ }^{14)}$, Svensson ら15)の方法を参考にして 5 項目の合計点にて 総合自覚症状(15点満点)を評価した.

5. MBP の分析：血液は午前 $10: 00$ から 2 時間の間に採取され，ただちに血清を分離後 $-80^{\circ} \mathrm{C}$ にて保存された．MBP 值は二抗体競 合法16) 18)により radioimmunoassay で測定さ れた。（測定は Mayo Medical Laboratoryに依 頼した.)

6 . 統計学的解析 : Wilcoxon 検定, Spearman の順位相関係数を用いて統計学的解析を 施行した. 危険率 $5 \%$ 未満 $(\mathrm{p}<0.05)$ を統計学 的有意差とした。

\section{結 果}

1. 自覚症状, 血中好酸球数および血清 MBP 值の各相関関係

飛散期 ( 3 月11日) での非初期治療群(10例) に おける総合自覚症状スコアと血中好酸球数また は血清 MBP 值の相関関係打よび血中好酸球数 と血清 MBP 值の相関関係を表 2 に示した. 未 治療の状態で総合自覚症状スコアと血清好酸球 数, 総合自覚症状スコアと血清 MBP 值, 血清
好酸球数と血清 MBP 值の相関関係を調べたが, いずれも有意な相関を示すには至らなかった。

2. 初期治療群と非初期治療群での各パラ メーターの比較

飛散中( 3 月11日)での初期治療群(10例)及び 非初期治療群 (10例)に拈ける総合自覚症状スコ ア, 血中好酸球数, 血清 MBP 值の比較を表 3 に示した. 総合自覚症状スコアと血清 MBP 值 に関しては危険率 $1 \%$ 以下で，血清好酸球数に 関しては初期治療群は危険率 $5 \%$ 以下で，初期 治療群は非初期治療群に比べて有意に抑制され た.

\section{考察}

スギ花粉症に括いて血中好酸球は飛散期に有 意に増加することが知られ，血液からもアレル ギーの病態を知ることができる16)，我々は，花 粉飛散期に打ける未治療のスギ花粉症患者の自 覚症状，血中好酸球数および血清 MBP 值の各 相関関係を検討するとともに，これらをパラ メーターとして用いて初期治療の効果をより客 観的データで評価した.

最近の研究により，好酸球扣よび顆粒蛋白が 鼻アレルギーの病態に深くかかわっていること が認められるようになってきた7) 13)。本研究

表 2 飛散期での非初期治療群(10例)における総 合自覚症状スコアと血中好酸球数または血 清 MBP 值の相関関係および血中好酸球数 と血清 MBP 值の相関関係 $(\mathrm{R}=$ 相関係数 $)$

\begin{tabular}{lcc}
\hline \hline & 血中好酸球数 & 血清 $M B P$ 值 \\
\hline 総合自覚症状スコア & $R=0.48$ N.S. & $R=0.41$ N.S. \\
血清 MBP 值 & $R=0.46$ N.S. & -
\end{tabular}

表 3 飛散期での総合自覚症状スコア, 血中好酸 球数抒よび血清 MBP 值に拈ける初期治療 群と非初期治療群の比較

\begin{tabular}{lcl}
\hline \hline & $\begin{array}{c}\text { 初期治療群 } \\
(10 \text { 例 }\end{array}$ & $\begin{array}{c}\text { 非初期治療群 } \\
(10 \text { 例 }\end{array}$ \\
\hline 総合自覚症状スコア & $3.6 \pm 3.5$ & $8.5 \pm 2.6^{* *}$ \\
血中好酸球数 $(/ \mu \mathrm{l})$ & $201 \pm 185$ & $364 \pm 162^{*}$ \\
血清 MBP 值 $(\mathrm{ng} / \mathrm{ml})$ & $483 \pm 111$ & $658 \pm 164^{* *}$
\end{tabular}


に括いては症例数が少ないため, 血中好酸球数 之自覚症状, 血清 MBP 值々自覚症状, 血中好 酸球数と血清 MBP 值のいずれも統計学的に有 意の相関関係を得るには至らなかった．しかし， これらの各相関係数は決して低值を示している わけではなく, 症例数の増加とともにこれらが 有意になる可能性が示唆された.

一方，近年花粉症に対する初期治療の有用性 が認められつつある4) 6). しかし, 自然飛散の 花粉症に対する初期治療の効果の評価は, 注之 んどが自覚症状のみで行なわれている. 本研究 では, 自覚症状に加兄血中好酸球数と血清 MBP 值を用いてょり客観性の高い評価を試み た. 花粉飛散中に执いて初期治療群は総合自覚 症状のみならず血中好酸球数, 血清 MBP 值も 非初期治療群に比較して有意に低值を示した。 これは，ケトチフェンが好酸球，MBP の上昇 を抑制する作用を持つ可能性を示している.さ らに，点鼻薬により血清 MBP 值が抑制される ことは, 血清中の MBP の上昇は大部分が鼻粘 膜からの再吸収によるものである可能性を示し ていると考えられる。

\section{まとめ}

自然飛散状態に打ける未治療のスギ花粉症患 者の自覚症状, 血中好酸球数捛よび血清 MBP 値の各相関関係を検討した。 さらに，これらを パラメーターとして用いて初期治療の効果をよ り客観的に評価することを目的として研究を施 行した.

血中好酸球数と自覚症状, 血清 MBP 值と自 覚症状, 血中好酸球数と血清 MBP 值のいずれ も有意の相関関係を得るには至らなかった。し かし, 各相関係数は低值ではなく, 症例数の増 加とともに有意になる可能性が示唆された。さ らに, ケトチフェン初期治療群は非初期治療群 と比較して有意に飛散中の血中好酸球数, 血清 MBP 值の上昇が抑制されることを提示し，こ れにより自覚症状が緩和される可能性を示すと ともに初期治療の効果をより客観的に評価した.

\section{参考文献}

1) Martin $U$ and Romer $D$ : The pharmacological properties of a new orally active antianaphylactic compound; ketotifen a benzocyclyheptathiophen. Arzeim-Forsch 28 : 770 782, 1978.

2) Ney UM, Bretz U, Martin U et al : Pharmacology of ketotifen. Res Clin Forumus $4: 9$ $\sim 16,1982$.

3) Kumagai $A$ and Tomioka $H$ : Pharmacological models for characterizing new antiasthmatics. Triangle $17: 135 \sim 140,1978$.

4) Businco L, Bellinoi P, Benincori N, et al : Oral ketotifen versus disodiumcromoglycate nasal spray for the prophylactic treatment of polleninduced allergic manifestations. Current Therapeutic Research 35 : 239 246, 1984.

5) Mellillo G, D'amato G, Cocco G, et al : Doubleblind placebo-controlled study on ketotifen in seasonal allergic rhinitis. Current Therapeutic Research 34 : 350 356, 1983.

6) Konno A, Yamakoshi T, Katagiri J, et al : The effect of topical use of antiallergic drugs on reactivity of the nasal mucosa to histamine. Otologia Fukuoka 36 : 252 257, 1990.

7) Gleich GJ, Loegering DA and Maldonado JE : Identification of a major basic protein in guinea pig eosinophil granules. J Exp Med 137: 177 $\sim 253,1986$.

8) Gleich GJ, Loegering DA, Mann KG, et al : Comparative properties of the Charcot-Leyden crystal protein and the major basic protein from human eosinophils. J Clin Invest $57: 633$ $\sim 640,1976$.

9) Motojima S, Frigas E, Loegering DA, et al : Toxicity of eosinophil cationic proteins for guinea pig tracheal epithelium in vitro. Am Rev Respir Dis 139 : 801 805, 1989.

10) Frigas E, Loegering DA and Gleich GJ : Cytotoxic effects of the guinea pig eosinophil major basic protein on tracheal epithelium. Lab Invest $42:$ 35 43, 1980.

11) O'Donnel MC, Ackerman SJ, Gleich GJ, et al : Activation of basophil and mast cell histamine release by eosinophil granule major basic pro- 
tein. J Exp Med 157 : 1981 1991, 1983.

12) Hisamatsu $K$, Ganbo $T$, Nakazawa $T$, et al : Cytotoxicity of human eosinophil granule major basic protein to human nasal mucosa in vitro. J Allergy Clin Immunol 1 : 52 63, 1990.

13) Andrew MB, Mikila RB, Vincent $C$, et al : Immunohistology of nasal mucosa in seasonal allergic rhinitis; increases in activated eosinophils and epithelial mast cells. J Allergy Clin Immunol 4 : 877 883, 1992.

14) Okuda $M$ : Classification of severity of nasal symptom in allergic rhinitis. Otolaryngology $55:$ 939 945, 1983.

15) Svensson C, Andersson M, Persson CGA, et al : Albumin, bradykinins, and eosinophil cationic protein on the nasal mucosal surface in patients with hay fever during natural allergen exposure. J Allergy Clin Immunol $5: 828 \sim 833$, 1990.
16) Wassom DL, Loegering DA, Solley GO, et al : Elevated serum levels of the eosinophil granule major basic protein in patients with eosinophilia. J Clin Invest $67: 651 \sim 661,1981$.

17) Wassom DL, Loegering DA and Gleich GJ : Measurement of guinea pig eosinophil granule major basic protein by radioimmunoassay. Mol Immunol $16: 711 \sim 719,1979$.

18) Frigas E, Loegering DA, Solley GO, et al : Elevated levels of the eosinophil granule major basic protein in the sputum of patients with bronchial asthma. Mayo Clin Proc 56 : 345 353, 1981.

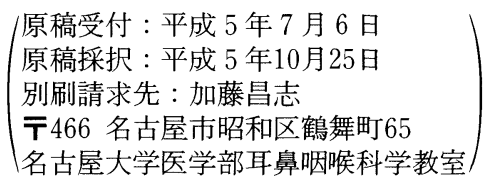

